\title{
Rancang Bangun Kontrol Pemadaman Listrik Rumah Via SMS Dengan Lampu Emergency Inverter
}

\author{
Yanuar Gustiyandi ${ }^{1)}$, Indah Sulistiyowati ${ }^{2)}$ \\ ${ }^{1,2)}$ Program Studi S1 Teknik Elektro \\ Universitas Muhammadiyah Sidoarjo
}

\author{
Kampus 2 : Jl. Raya Gelam 250 Candi \\ ${ }^{1)}$ Email : Yanuargustiyandi4@gmail.com \\ ${ }^{2)}$ Email : Indahsulistiyowati@yahoo.co.id
}

\begin{abstract}
Abstrak - . Listrik adalah sumber energi utama yang dibutuhkan manusia untuk kehidupan seharihari, tanpa listrik manusia tidak bisa menyalakan televisi, lemari es, dan yang pasti akan gelap karena tidak bisa menyalakan lampu pada malam hari. Oleh karena itu listrik sangatlah penting dan bisa menjadi kebutuhan utama dalam hidup ini, akhirakhir ini sering terjadi pemadaman listrik secara bergiliran yang dilakukan oleh PLN. Yang menjadi masalah adalah ketika malam hari terjadi pemadaman listrik maka rumah akan gelap karena lampu juga pasti akan mati, dan pada saat itulah dibutuhkan sebuah alat untuk menghidupkan lampu rumah agar mampu menerangi rumah ketika terjadi pemadaman listrik. Alat itu adalah inverter yang dijalankan oleh accu dengan tegangan 12 volt DC yang menggantikan tegangan 220 volt dari PLN dan juga dapat mengontrol via SMS jika sewaktu-waktu terjadi pemadaman listrik. Rangkaian inverter akan aktif ketika terjadi pemadaman listrik dan arduino sebagai mikrokontroller mentrigger modul sms SIM 900 untuk mengirimkan pesan ke pemilik rumah untuk mengkonfirmasi inverter di aktifkan atau tidak, jika inverter aktif maka lampu akan hidup dan jika inverter tidak aktif maka lampu akan tetap mati. Sehingga akan dihasilkan alat kontrol pemadaman listrik rumah via sms dengan lampu emergency yang dijalankan oleh inverter DC to $\mathrm{AC}$.
\end{abstract}

Kata kunci : ARDUINO, ACCU, INVERTER, SIM900.

Abstract -. Electricity is the main source of energy that humans need for everyday life, without electricity a human can not turn on the television, the fridge, and which is sure to be dark because it can not turn on the lights at night. Therefore electricity is very important and can be a major requirement in this life, recently there are frequent blackouts in turn by PLN. The problem is that during the night there is a blackout the house will be dark because the lights will also die, and that's when it takes a tool to turn on the house lights to be able to illuminate the house when there is a power outage. The tool is an inverter run by batteries with 12 volt $D C$ voltage that replaces 220 volt voltage from $P L N$ and also can control via SMS if at any time of power outage. The inverter circuit will be active when there is a power outage and the arduino as a microcontroller triggers the SIM 900 sms module to send a message to the homeowner to confirm the inverter is activated or not, if the inverter is active then the lamp will turn on and if the inverter is off then the lamp will stay off. So that will be generated appliance control of house electricity blackout by sms with emergency lamp run by $D C$ to $A C$ inverter.

Keywords: ARDUINO, ACCU, INVERTER, SIM900.

\section{PENDAHULUAN}

\subsection{Latar Belakang}

Pada era modern seperti saat ini listrik adalah sumber energi utama yang dibutuhkan manusia untuk kehidupan sehari-hari, tanpa listrik manusia tidak bisa menyalakan televisi, lemari es, dan yang pasti akan gelap karena tidak bisa menyalakan lampu pada malam hari. Oleh karena itu listrik sangatlah penting dan bisa menjadi kebutuhan utama dalam hidup ini, akhir-akhir ini sering terjadi pemadaman listrik secara bergiliran yang dilakukan oleh PLN. Yang menjadi masalah adalah ketika malam hari terjadi pemadaman listrik maka rumah akan gelap karena lampu juga pasti akan mati, dan pada saat itulah dibutuhkan sebuah alat untuk menghidupkan lampu rumah agar mampu menerangi rumah ketika terjadi pemadaman. Alat itu adalah inverter yang dijalankan oleh accu dengan tegangan 12 volt DC yang menggantikan tegangan 220 volt dari PLN 


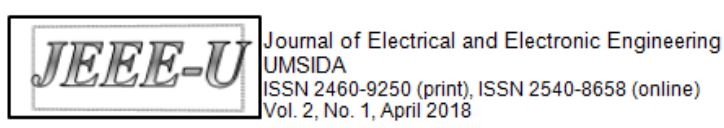

dan juga dapat mengontrol via SMS jika sewaktu-waktu terjadi pemadaman listrik.

Maka dibuatlah sebuah penelitian rancang bangun kontrol pemadaman listrik rumah via sms dengan lampu emergcy inverter yang berfungsi untuk mengabarkan pada pemilik rumah jika terjadi pemadaman listrik melalui modul sms sim900a dan jika pemilik rumah ingin menyalakan lampu emergency inverter, pemilik rumah cukup dengan membalas sms ke nomor yang dipakai pada modul gsm sim900a sesuai dengan input kata yang ada pada program skets arduino.

\section{TINJAUAN PUSTAKA}

\subsection{Modul GSM SIM 900}

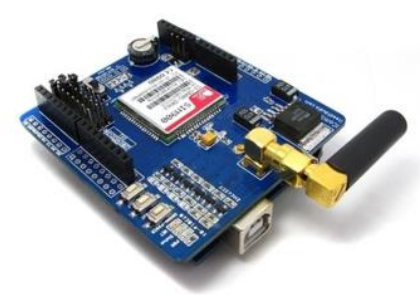

\section{Gambar 2.1 modul GSM SIM 900 [4]}

Modul GSM dengan chip SIM900 ini bisa dipakai untuk project sms gateway atau kontrol dan monitoring via SMS dan GPRS Modul gsm ini dapat dihubungkan langsung ke mikrokontroller ataupun juga melalui komunikasi RS232. Didalam modul GSM ini terdapat header selektor yang berfungsi untuk memilih komunikasi TTL atau RS232. Sangat berguna untuk project kontrol via sms atau monitoring sms karena penggunaan nya yang sangat sederhana serta ringkas.

\subsection{Arduino Uno}

Arduino adalah mikrokontroller single-board dengan rsifat open-source, dirancang untuk memudahkan penggunaan elektronik dalam berbagai bidang. Hardware (perangkat keras)-nya menggunakan prosesor At-Mega AVR dan software (perangkat lunak)-nya menggunakan bahasa pemrograman sendiri. Open source IDEyang digunakan untuk membuat aplikasi mikrokontroler yang berbasis platform arduino. Mikrokontroler single-board ini bersifat open source, hardwareyang digunakan dan dikembangkan untuk arsitektur mikrokontroller AVR 8 bit dan ARM 32 bit. 10.21070/jeee-u.v\%vi\%i.1513

\subsection{Inverter}

Inverter adalah sebuah rangkaian elektronika daya yang digunakan untuk mengubah atau mengkonversi tegangan searah (DC) menjadi tegangan bolak-balik (AC). Inverter adalah kebalikan dari converter (adaptor) yang mempunyai fungsi untuk merubah tegangan bolak-balik (AC) menjadi tegangan searah (DC). Pada saat ini terdapat beberapa tipologi inverter, mulai dari inverter yang digunakan hanya untuk menghasilkan tegangan bolak-balik saja (push-pull inverter), tetapi juga sampai dengan inverter yang mampu menghasilkan tegangan sinus murni tanpa harmonisasi. Selain itu inverter juga dapat diklasifikasikan menjadi beberapa bagian berdasarnya fasanya, mulai dari satu fasa, tiga fasa, sampai dengan multifasa. Inverter mempunyai fungsi untuk mengubah tegangan searah (DC) menjadi tegangan bolak-balik (AC). Perubahan itu dilakukan dengan cara mengubah kecepatan motor AC dengan hanya mangubah frekuensi outputnya. Jadi bisa dibilang inverter ini multifungsi, dapat mengubah arus AC ke DC, lalu mengembalikannya lagi ke AC.Inverter sering digunakan dalam bidang otomatisasi industri. Pengaplikasian inverter biasanya terpasang pada proses linear (parameter yang bisa diubah-ubah). Linear yang dimaksud adalah memiliki bentuk seperti grafik sinus, atau untuk sistem axis (servo) yang membutuhkan atau memerlukan putaran yang presisi. Cara kerja inverter ini dilakukan dengan cara mengubah input motor listrik AC menjadi DC, yang kemudian diubah lagi menjadi AC dengan frekuensi yang diinginkan, sehingga motor listrik tersebut dapat dikontrol atau dikendalikan sesuai dengan kecepatan yang diinginkan.Skema Inverter atau Rangkaian Merubah Tegangan DC 12 volt Menjadi AC 230 volt. inverter bisa juga di sebut sebagai perubah tegangan salah satunya merubah tegangan DC volt menjadi AC volt.

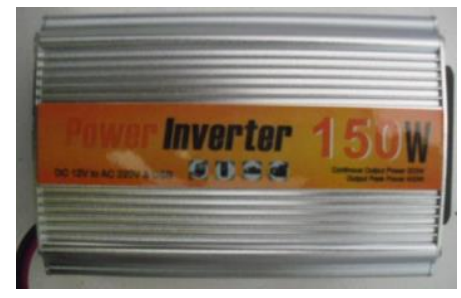

Gambar 2.2 rangkaian inverter 150 watt (Sumber: www.energinonfosil.wordpress.com) 


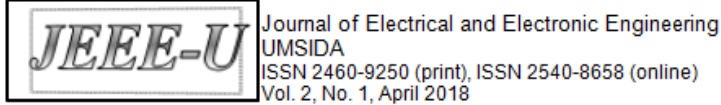

Table 2.3 spesifikasi inverter 150 watt

\begin{tabular}{|c|c|c|c|c|}
\hline $\begin{array}{c}\text { Tegangan } \\
\text { input }\end{array}$ & Arus & $\begin{array}{c}\text { Tegangan } \\
\text { output }\end{array}$ & $\begin{array}{c}\text { Daya } \\
\text { output }\end{array}$ & $\begin{array}{c}\text { Daya } \\
\text { output } \\
\text { max }\end{array}$ \\
\hline 12 volt Dc & $\begin{array}{c}12 \\
\text { Ampere }\end{array}$ & $\begin{array}{c}200-230 \text { volt } \\
\text { Ac }\end{array}$ & 150 watt & $\begin{array}{c}70 \% \\
=100 \\
\text { watt }\end{array}$ \\
\hline
\end{tabular}

\subsection{Accumulator (accu/aki)}

Accumulator atau sering disebut aki adalah battery yang berfungsi sebagai alat yang dapat menyimpan energi (umumnya energi listrik) dalam bentuk energi kimia. Contoh-contoh akumulator adalah baterai dan kapasitor.Pada umumnya di Indonesia, kata akumulator (sebagai aki atau accu) hanya dimengerti sebagai baterai mobil. Sedangkan di bahasa Inggris, kata akumulator dapat mengacu kepada baterai, kapasitor, kompulsator, lan - lain. di dalam standar internasional setiap satu cell akumulator memiliki tegangan sebesar 2 volt. sehingga aki 12 volt, memiliki 6 cell sedangkan aki 24 volt memiliki 12 cell.Aki merupakan sel yang banyak kita jumpai karena banyak digunakan pada sepeda motor maupun mobil. Aki temasuk sel sekunder, karena selain menghasilkan arus listrik, aki juga dapat diisi arus listrik kembali. secara sederhana aki merupakan sel yang terdiri dari elektrode $\mathrm{Pb}$ sebagai anode dan $\mathrm{PbO} 2$ sebagai katode dengan elektrolit $\mathrm{H}_{2} \mathrm{SO}_{4}$.

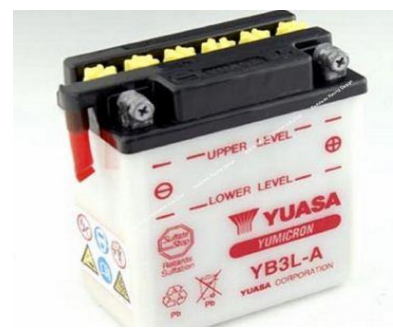

Gambar 2.3 accumulator (accu/aki) (Sumber:https://indonesian.alibaba.com) 10.21070/jeee-u.v\%vi\%i.1513

\begin{tabular}{|c|c|}
\hline EAN code & Nvt \\
\hline Gewicht & 1.700 gr. \\
\hline Accu voor & Nvt \\
\hline Part nummer: & NP4-12 \\
\hline Accu type & Loodaccu - AGM \\
\hline Output Voltage & 12 Volt \\
\hline Accu capaciteit & Loodaccu - AGM \\
\hline Batterij technologie & Nvt \\
\hline Accu aansluiting & NP4-12 \\
\hline Model nummer: & $90 / 70 / 106$ mm \\
\hline L $\mathbf{x}$ B x H in mm & Nvt \\
\hline Type omschrijving: & Nvt \\
\hline Herstelercode & Yuasa NP Standaard \\
\hline Accu - Batterij & \\
\hline
\end{tabular}

\subsection{Relay}

Relay adalah suatu switch yang digerakkan secara elektris, yang didalamnya terdapat kontak berupa kondisi NO (Normaly Open) dan NC (Normaly Close) yang nantinya dapat digunakan sebagai pengontrolan suatu rangkaian.

\section{METODOLOGI PENELITIAN \\ 3.1 Blok Diagram}

Metode yang dipakai menggunakan sistem sms sebagai pemberi informasi menggunakan modul SIM 900 yang akan mengirim sms ke pengguna ketika listrik padam dan mengaktifkan cadangan energi menggunakan inverter secara otomatis melalui program yang sudah dibuat pada software arduino. Berikut adalah blok diagram dari system sekarang yang akan di tunjukkan pada Gambar 3.1 dibawah ini :

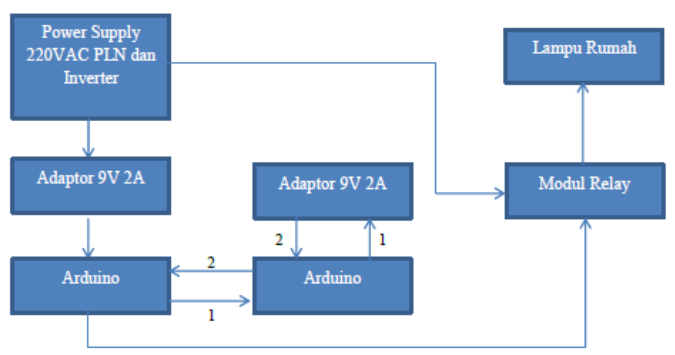

Gambar 3.1 Blok Diagram Sistem 
Dalam diagram blok diatas dapat dijelaskan bahwa pada penelitian ini supply utama ada 2 yaitu dari PLN dan dari inverter untuk menghidupkan adaptor yang mensupply daya 9 volt DC ke arduino,dari arduino menuju ke modul GSM SIM900A yang akan mengirim pesan nomor pemilik rumah, jika pemilik rumah membalas ( lampu on) maka modul relay akan menyalakan lampu dengan cadangan energi dari accumulator dan inverter.

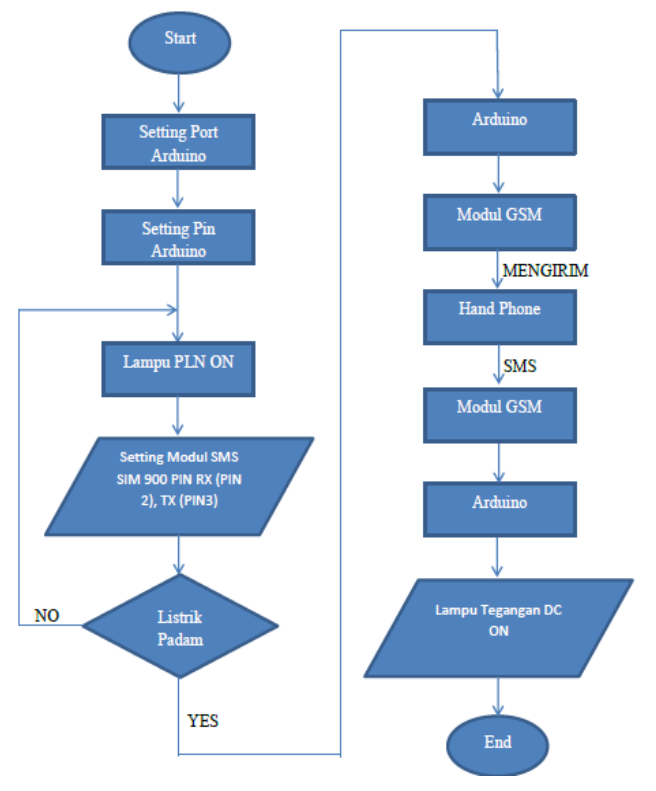

Gambar 3.2 Blok Diagram Sistem

\subsubsection{Flow Chart Sistem}

Flow chart sistem keseluruhan rangkaian mulai dari start, setting com port arduino, mendeklarasikan variable constanta, dan mengkofigurasi pin $\mathrm{I} / \mathrm{O}$, masuk ke mode perintah yang sebelumnya disetting oleh output arduino, pengolahan data, output arduino berupa perintah menyalakan mematikan lampu emergency dari jarak jauh via sms ketika listrik padam. Berikut adalah flow chart yang akan di tunjukkan pada Gambar 3.2 sebagai berikut :

\section{HASIL DAN PEMBAHASAN}

\subsection{Hasil Pengujian}

Dalam pengujian secara langsung untuk mengetahui berapa lama accu bias menyuplay lampu selama terjadi listrik padam, Berikut hasil dari pengujan tersebut;
Tabel 4.1 Hasil Pengujian Mengirim Sms

\begin{tabular}{|c|c|c|c|c|c|c|}
\hline No. & Keadaar. Listrk & $\begin{array}{l}\text { Menginim } \\
\text { SMS } \\
\left(\mathrm{Y}_{2} / \mathrm{Tic}_{\mathrm{c}} \mathrm{k}\right)\end{array}$ & $\begin{array}{c}\text { Menenima } \\
\text { sms } \\
\text { Ya/Tijak) }\end{array}$ & $\begin{array}{l}\text { Relay } \\
\text { (On/Off) }\end{array}$ & $\begin{array}{c}\text { Emergency } \\
\text { Lamp } \\
(\mathrm{Om} / \mathrm{Off})\end{array}$ & Hasil Pengujian \\
\hline 1. & Listrik padam. & $\mathrm{Ya}_{\mathrm{a}}$ & $\mathrm{Ya}_{\mathrm{a}}$ & Or. & Or. & Berhasil \\
\hline 2. & Listrik padam. & $\mathrm{Y}_{\mathrm{a}}$ & $\mathrm{Y}_{\mathrm{a}}$ & Or. & Or. & Berhasil \\
\hline 3. & Listrik padam. & $\mathrm{Y}_{2}$ & $\mathrm{Y}_{2}$ & Or: & $\mathrm{Or}$ & Berhasil \\
\hline
\end{tabular}

Tabel 4.2 Pengujian lamanya lampu rumah ON dengan cadangan energy

\begin{tabular}{|c|c|c|c|c|c|c|}
\hline \multirow{2}{*}{ No } & \multirow{2}{*}{$\begin{array}{l}\text { Percobaan } \\
\text { (menitke) }\end{array}$} & \multicolumn{4}{|c|}{$\begin{array}{c}\text { Kondisi battery (volt) } \\
\text { Percobaan ke }\end{array}$} & \multirow{2}{*}{$\begin{array}{l}\text { Kondisi } \\
\text { Lampu }\end{array}$} \\
\hline & & 1 & 2 & 3 & Rata-rata & \\
\hline 1 & 30 menit & 12.3 & 12.2 & 12.2 & 12.23 & Terang \\
\hline 2 & 60 menit & 10.5 & 10.4 & 10.9 & 10.6 & Terang \\
\hline 3 & 90 menit & 7.9 & 8.2 & 8.1 & 8.06 & Redup \\
\hline 4 & 120 menit & 6.3 & 6.4 & 6.4 & 6.36 & Redup \\
\hline
\end{tabular}

\section{Percobaan ke 1.}

Dari data percobaan ke 1dengan melakukan pengambilan data secara $4 \mathrm{kali}$, pengambilan data pengujian diambil dari perbedaan lamanya lampu dari inverter yang di supplay dari accu,yaitu 30,60,90 dan 120 menit.

Berikut Grafik percobaan ke 1.

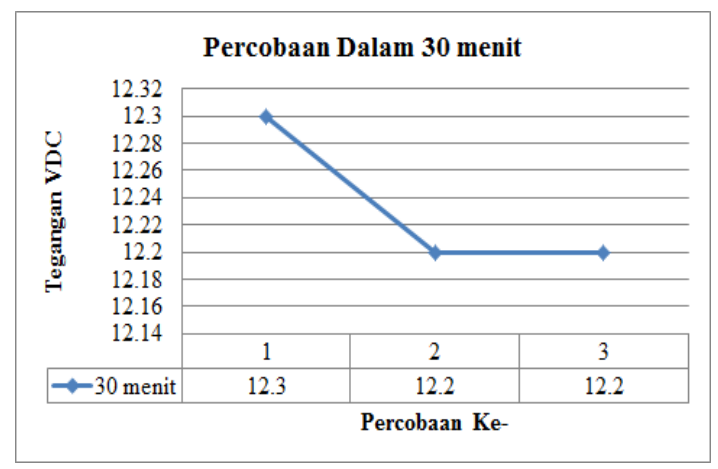

\section{Percobaan ke 2.}

Dari data percobaan ke 2 dengan melakukan pengambilan data secara 4 kali, pengambilan data pengujian diambil dari perbedaan lamanya lampu dari inverter yang di supplay dari accu,yaitu 30,60,90 dan 120 menit. 
Berikut Grafik percobaan ke 2.

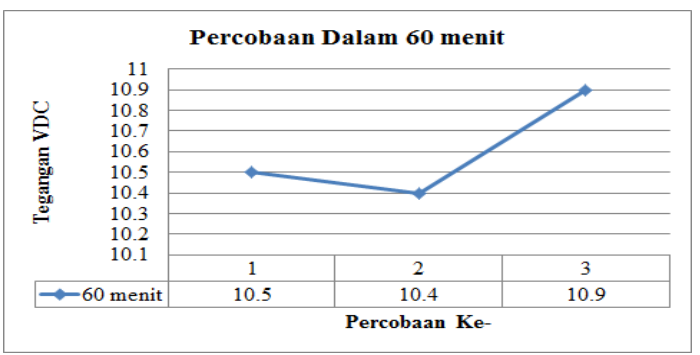

\section{Percobaan ke 3}

Dari data percobaan ke 3 dengan melakukan pengambilan data secara 4 kali, pengambilan data pengujian diambil dari perbedaan lamanya lampu dari inverter yang di supplay dari accu,yaitu 30,60,90 dan 120 menit.

Berikut Grafik percobaan ke 3 .

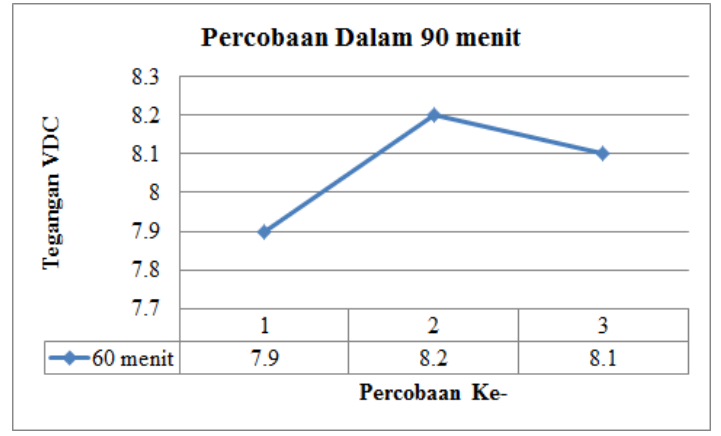

\section{Percobaan ke 4}

Dari data percobaan ke 4 dengan melakukan pengambilan data secara 4 kali, pengambilan data pengujian diambil dari perbedaan lamanya lampu dari inverter yang di supplay dari accu,yaitu 30,60,90 dan 120 menit.

Berikut Grafik percobaan ke 4.

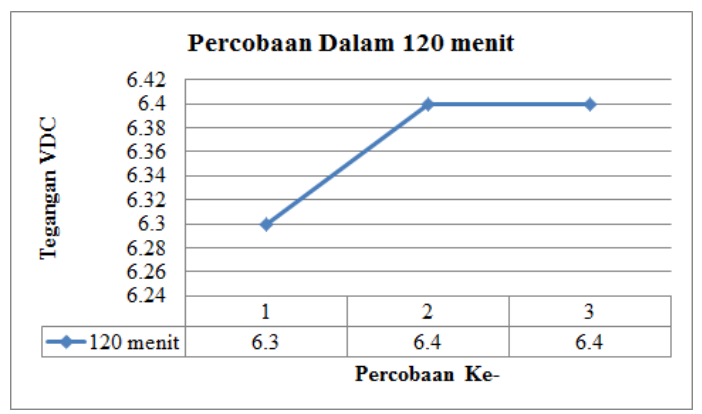

\section{Rata-rata Percobaan ke}

Dari data rata-rata percobaan dengan melakukan pengambilan data secara $4 \mathrm{kali}$, pengambilan data pengujian diambil dari perbedaan lamanya lampu dari inverter yang di supplay dari accu,yaitu 30,60,90 dan 120 menit.

Berikut Grafik rata-rata percobaan.

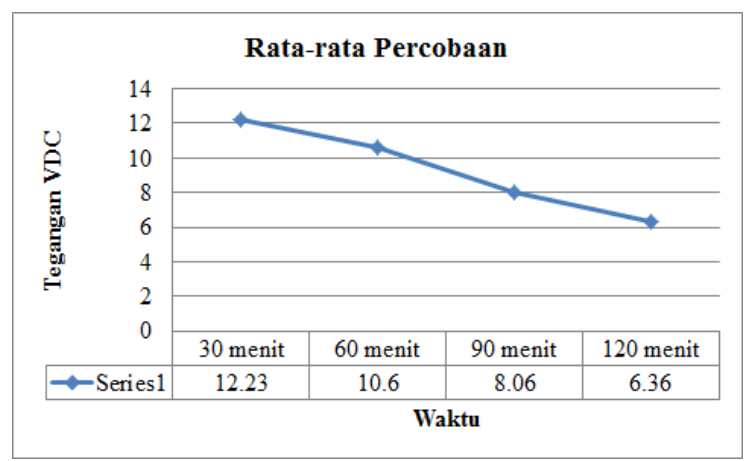

\subsection{Analisa Hasil Pengujian}

1. Semakin lama accu digunakan tanpa dilakukan pengecasan, maka tegangan accu akan semakin kecil hal tersebut berdampak pada lampu yaitu sinar lampu semakin redup.

2. Dimanapun dan kapanpun user berada akan dapat menerima SMS dari Modul GSM selama masih terjangkau oleh sinyal selular dari handphone yang dipakai.

\section{KESIMPULAN}

Dari setiap tahap yang telah dilakukan dalam pengujian dapat diambil kesimpulan sebagai berikut:

1. Dengan menggunakan perangkat keras berupa rangkaian mikrokontroller (arduino dan Modul GSM SIM900A) informasi SMS dapat memberitahukan bila terjadi pemadaman listrik pada rumah meskipun penghuni rumah tidak berada dirumah karena pemilik rumah akan mendapat informasi melalui sms dan dengan membalas sesuai dengan program di arduino pemilik rumah bisa menyalakan lampu emergency ketika terjadi pemadaman listrik sesuai dengan hasil pengujian diatas.

2. Dengan menggunakan Modul GSM SIM900A GSM/GPRS yang telah diatur oleh program arduino dapat berjalan dengan baik dan menghasilkan sinyal yang baik, terbukti dari hasil pengujian yang ditunjukkan diatas. 


\section{SARAN}

Kedepannya, untuk kesempurnaan alat kontrol pemadaman listrik rumah via sms dengan lampu emergency inverter ini bisa ditambahkan rangkaian charger otomatis untuk aki dan ditambahkan LCD pada rangkaian untuk melihat hasil percobaan secara detail, dan perlu penelitian lebih lanjut agar alat ini dapat lebih bermanfaat.

\section{DAFTAR PUSTAKA}

[1] Pengendalian Listrik Rumah Berbasis Mikrokontroller Arduino Menggunakan Smartphone Android.

[2] Perancangan Sistem Keamanan Rumah Berbasis SMS Gateway Menggunakan Mikrokontroller Arduino AT-Mega 2560.

[3] Prototipe kontrol Lampu Berbasis Android Dengan Pengingat Via SMS.

[4] Rancang Bangun Alat Monitoring Arus dan Tegangan Berbasis Mikrokontroler dengan SMS Gateway.

[5] Ebook 17 Proyek Belajar Arduino.

[6] Panduan Praktis Arduino Untuk Pemula Trenggalek, 15 Juli 2015.

[7] Aplikasi Pengontrol Jarak Jauh Pada Lampu Rumah Berbasis Android. Kadir, Abdul. 2012. Panduan Praktis Mempelajari Aplikasi Mikrokontroller dan Pemrogramannya menggunakan Arduino. Yogyakarta 2012. 